\title{
Managing intersubjectivity and establishing consensus in two activity types: business negotiations and student workgroups
}

\begin{abstract}
Two discursive processes constitute the focus of this study: intersubjectivity management and argumentation. Intersubjectivity management (ISM) is a newly coined term referring to a set of conversational phenomena, which are regarded as manifestations of a comprehensive process whereby common ground and mutual understanding are coconstituted in dialogue. This process takes place at the micro-level of dialogue and is implemented by means of signals which are usually backgrounded and, more often than not, multi-modal. Argumentation, in turn, constitutes a far more explored field of research. In the present framework, argument management (AM) is regarded as a process which is situated at the macro-level of dialogue and is an essential factor in the global organisation of dialogue.

The aim of the present article is to shed light on ways in which ISM and AM are conjoined and used as tools for consensus establishment and conflict-solving within two related activity types, each situated in an institutional setting: business negotiations and problem-solving in university students' workgroups. Both sets of data are based on videorecordings of multi-party dialogues carried out in two varieties of Spanish: peninsular Spanish in the business negotiation (elicited data) and Chilean Spanish in the students' workgroup (naturally occurring data).

The conjoined analysis of ISM and AM processes shows that AM moves become effective only when supported by appropriate ISM signalling. In particular, acceptance moves will lead to consensus only if they are combined with ISM devices which signal a high degree of common ground.
\end{abstract}

Keywords. Argumentation structure, consensus establishment, dialogue analysis, feedback, intersubjectivity, multimodality.

Word count. Main text including endnotes, 7057 w. Reference list, 846 w. Appendix, 837 w. Abstract, 254 w. Bio-blurb, 94 w.

Lars Fant

Dept. of Spanish, Portuguese and Latin American Studies (ISPLA)

Stockholm University

SE 10691 Stockholm (Sweden)

lars.fant@isp.su.se

Lars Fant is professor of Ibero-Romance languages at Stockholm University. His main research fields are cross-cultural studies and intercultural communication (Hispanic vs. Scandinavian), critical discourse analysis, rapport management and politeness phenomena, modalisation processes in discourse, communication management in conversation and highproficient second language use. At Stockholm University he has conducted several large-scale research projects, such as 'Negotiation interaction: cross-cultural studies of Scandinavian and Hispanic patterns' and 'Activity types and conversation structure in native and non-native (Swedish) speakers of Spanish'. At present he is co-conducting a research programme titled 'High-level proficiency in second language use'. 
Introduction. Problem-solving is a central component in an extensive array of human activity types involving various forms of spoken and written communication. The study of problem-solving interaction in face-to-face encounters is a domain which until present has been just a marginal concern in Hispanic pragma- and sociolinguistics. The aim of this contribution is to shed light on a few general mechanisms involved in problem-solving, with particular focus on two institutional activity types, which in certain respects have traits in common but are also very different with regard to the genre rules they are governed by. The first of these, which we can label 'business negotiation interaction', is characterised by the distribution of its participants into two (or more) parties with partially conflicting, partially convergent interests (Donohue 1981: 274). The interaction patterns found in this activity type are more often than not confrontational and openly argumentative in nature. The second activity type to be approached could best be termed 'problem-solving in students' workgroups' (Harvey 2006). The interaction here is one which takes place when university students meet in order to find joint solutions to tasks they have received in the course of their studies ${ }^{\mathrm{i}}$.

The data drawn on for analysing interaction of the first activity type is a transcribed recording of a simulated negotiation performed in Spanish between two teams of professional business people. It can best be described as elicited data, albeit with a spontaneously occurring dialogue which no doubt reflects the participants' behaviour patterns in the naturally occurring professional situations they are closely familiar with. One of the teams consists of two Swedish people who live in Spain and are highly proficient users of their L2 Spanish, while the second team is made up of two native speakers of Peninsular Spanish. As regards the second activity type -students' workgroups-, the data is a transcribed recording of a naturally occurring multi-party interaction whose participants are Chilean higher education students. The recording was taken from the extensive GRUPES corpus (Harvey 2006; Fant and Harvey in press; Núñez and Oyanedel in press). Both sets of data were transcribed according to the Transana system (for details, see site: www.transana.org).

In order to account for the mechanisms of problem-solving, two theoretical models will be resorted to. One of these models (Gille 2001) concerns the ideational and discursive plane of communication and involves the notions of argumentation and argument management. The analysis regarding this plane will be referred to as macro-level analysis in the present context. The second model involves mechanisms of the interactional plane of communication and addresses a group of phenomena under the heading 'intersubjectivity management' (Fant 2007a and 2007b; Fant and Harvey in press); the corresponding analysis will henceforth be referred to as micro-level analysis.

Although the present study may be seen as explorative in the sense of applying models of analysis to empirical interactional data, it is also driven by specific research questions. The first and encompassing question is by which linguistic means participants in conflict- and problem-solving seek and obtain consensus in dialogue. The second question concerns which particular effects the establishment of consensus has on topic selection and topic management. Thirdly, considering that two distinct planes of analysis are involved (and provided the proposed models of argumentation and intersubjectivity management prove operational), a natural question that arises is to what extent these two processes are interdependent.

Intersubjectivity management. Intersubjectivity, taken in a broad social-psychological sense, can be said to refer to a state of focus, knowledge, understanding and appraisal shared by two or more participants of a communication event, at a particular point of that event. In this sense, it is closely related to the concepts of mutual knowledge (Clark and Marshall 1981; Gibbs 1987) and common ground (Cicourel 1973; Clark 1996). The notion of 
intersubjectivity has been used by Mikhail Bakhtin (see e.g. Bakhtin 1986 or Bubnova 2000) and has been developed and elaborated by Ragnar Rommetveit in a number of studies, in particular Rommetveit (1979) and (1985). It has also been used by e.g. John Heritage (Heritage 1984), James V. Wertsch (Wertsch 1991 and 1998) and Per Linell (Linell 1998) to refer not only to a cognitive but also to an affective state existing between interactants.

In the present context, however, intersubjectivity (henceforth: IS) will be understood in a more restricted sense, directly related to the structure of dialogue and describable in terms of use of specific linguistic devices which have specific functions and produce specific effects. The proposed model for intersubjectivity management (henceforth: ISM) draws largely on work on feedback processes in speech such as Yngve (1970), Schegloff (1982), or Allwood, Nivre and Ahlsén (1992), and, as regards Spanish, Fant (1996), Briz (1998) and Vázquez Veiga (2000). It also draws on the model for initiative/response-analysis proposed by Linell, Gustavsson and Juvonen (1988), earlier applied e.g. by Fant (1996) and Briz (1998). ISM is regarded as co-constructional action (Jacoby and Ochs 1995) and as an essential component in the process of co-constitution in dialogue (Linell 1998: 87; Arundale 1999: 127-129). It deserves underscoring that this process is more often implemented by means of bi- or multi-modal devices (cf. Taylor, Neel and Bouwhuis, eds., 1989) than with purely verbal markers.

By means of ISM devices, the participants of a dialogue - regardless of whether it takes place within an institutional activity or not - can be said to 'negotiate' the extent to which the ideational and pragmatic content expressed will be accepted as shared knowledge and give rise to a mutual understanding. It is assumed that interactants, motivated by their willingness to cooperate, will by default (though far from always) strive to establish or restore a maximum degree of IS. This is done repeatedly and in short intervals throughout the event. It is assumed that the distribution of ISM devices is coordinated with the division of turns into dialogue units (or turn-constructional units; Sacks, Schegloff and Jefferson 1974), so that for each unit, an ISM signal is expected to be produced.

Two basic types of ISM acts are involved: affirmative acts of claiming or confirming IS and avoidance acts of refraining from claiming or confirming IS. Depending on whether an act belongs to an initiative or a response move, it will be understood as either (refraining from)claiming or (refraining from) confirming, respectively.

Furthermore, affirmative acts are taken to be produced along a scale (Fant 2005) that comprises six degrees: maximum IS (+3), high IS $(+2)$, some IS $(+1)$, some lack of IS (-1), low IS (-2), and minimum IS (-3). However, only confirming acts can take all six values, whereas claiming acts are assumed to range across four values only, from +2 to -2 . This assumption is based on the consideration that, since IS is a co-constructed state and ISM a coconstitutive process, true co-constitution can only occur in and through a confirmation act. Accordingly, maximum degrees $(+3$ and -3$)$ are attributed only to confirmation acts.

ISM devices can be seen as operators on propositional content. IS-claiming devices operate on content expressed by the speaker itself, whereas IS-confirming devices operate on content expressed by the previous speaker (except, of course, in case the speaker who produces the confirming device is enacting two parallel voices in the same turn). Only by means of ISM devices that confirm maximum $(+3)$ or high $(+2)$ degree will positive IS be coconstitutively attained with regard to a given topic.

IS can be seen as consisting of a cognitive and an affective component. The cognitive component will be referred to as 'shared knowledge' and the affective component as 'mutual understanding'. By signalling mutual understanding, the speaker conveys to the interlocutor(s) that the evaluation of the current topic is shared. 
Verbal markers. Two functional categories of verbal markers are involved in ISM: feedbackclaiming expressions, which are used in initiative moves, and feedback-giving expressions, which are used in response moves. Whereas the latter category has been accounted for theoretically in several studies, among which Allwood et al (1992) deserves particular attention, and both categories have been the subject of a large number of empirical studies, surprisingly little work has addressed both categories as manifestations of a holistic process. The most typical representatives of feedback-claiming in English, the so-called tag questions (isn't it?, don't they?, wouldn't we?, etc.) have been thoroughly described from various perspectives, whereas functionally corresponding expressions in Spanish such as ¿no?, ¿si??, ¿(no es) verdad? or ¿(no es) cierto? have not been as lucky ii.

Feedback-givers can be considered as having two separate functions: the minimalresponse function and a back-channelling function. The difference between the two is that while minimal responses are turn-claiming in nature and are often used as the starting point of a new turn, back-channelers - though typically occurring at transition-relevance points (Sacks, Schegloff and Jefferson 1974) - are not understood as claiming the turn from the current speaker. The division line is fuzzy, however, for the reason that turn-claiming depends on many different contextual factors and, above all, that one and the same formal marker can often do both jobs.

Frequent feedback-givers which occur in all varieties of Spanish are $\mathrm{mm}$ ('message received'), ya ('message received and understood'), claro ('message received, understood and judged to be obvious information'), si ('message received and understood' + 'confirming the non-negated propositional content of the preceding utterance'), no ('message perceived and understood' + 'claiming the opposite of the non-negated propositional content of the preceding utterance'), and $a h$ ('message received, understood and judged to be new or dissonant information'; this marker often combines with sí, no, ya or claro).

Prosodic markers. Although verbal markers are essential devices in ISM, prosodic signals should be considered just as important. Among the various types of prosodic markers, endtones (i.e. intonational contours appearing at the end of tone groups) seem to be the category most closely connected with ISM (Brazil 1997; Fant 2006). Simple end-tones may be distinguished from composite end-tones. In Spanish - and presumably in most languages -, three simple end-tones may be distinguished (cf. Navarro Tomás 1944):

$\uparrow=$ rising tone, understood as signalling low or minimum IS. When closing an initiative move, the typical intended interpretation is 'request for response', which corresponds to the traditional notion of question. However, in an initiative move which corresponds to a dialogue unit (turn-constructional unit) where the speaker selects him-/ herself as next speaker (Sacks et al 1974), the signalling of low IS is reinterpreted as a mere continuity signal. When ending a feedback-claiming (initiative) move, the intended interpretation is 'request for confirmation'. In feedback-giving (response) moves, finally, the rising tone (e.g. si $\uparrow$ 'yes $\uparrow$ ') is normally meant to be interpreted as a request for additional content.

$\downarrow=$ falling tone, understood as signalling high or maximum IS. In initiative moves, the falling end-tone is generally perceived as a 'declarative' signal, i.e. as a claim of shared knowledge. In response moves, the falling end-tone is used for confirming that the content of preceding turn represents shared knowledge.

$\rightarrow=$ level tone, understood as 'refraining from signalling any degree of IS'. This value represents the same meaning regardless of whether the tone appears in an initiative or a response move. 
As regards composite end-tones, the model proposed in Fant (2006) predicts that both aspects of intersubjectivity - shared knowledge and mutual understanding - are signalled separately in the sense that the first part of the composite tone represents mutual understanding and the second part shared knowledge. The most frequent composite tone in the activity types under consideration appears to be the rise-fall $(\uparrow \downarrow)$, which is understood as low mutual understanding plus high shared knowledge. The contradictory nature of this signal meaning something like 'we share this information though we may not see it in the same way', explains its connotation of emphasis or accentuated commitment. This connotation is present both in initiative and response moves.

The opposite type of composite end-tone, the fall-rise $(\downarrow \uparrow)$, presumably signals the inversion of the meaning of the rise-fall, namely high mutual understanding plus low shared knowledge. This type of signal, which means something like 'we see these things in the same way but there is a piece of information that we do not share', is likely to appear in polite or rhetorical questions used for underscoring the speaker's willingness to reach consensus. In response moves, the fall-rise typically seems to be used to hedge the signalling of non-shared knowledge (ah si $\downarrow \uparrow$ 'really $\downarrow \uparrow$ ').

Mutual contextualisation between verbal and prosodic markers. Prosodic signals never occur in isolation (when they seemingly do, they are in fact superimposed on non-verbal vocalisations). Verbal discourse markers, in turn, can hardly be produced without a cooccurring prosodic signal. Verbal and prosodic components jointly build a complex bi-modal signal where the prosodic part provides the immediate context for the verbal part, and vice versa (cf. Selting 1996). To complicate things further, gesture often enters the picture giving rise to even more complex, multi-modal signals.

The following exchange is an example of basic bi-modal signalling in ISM:

A: Tienes hambre, ¿no ? ('You're hungry, aren't you?')

B: Sí, un poco. ('Yes, a little.')

Here, the verbal discourse marker ¿no? combines with a rising end-tone $(\uparrow)$ into a bi-modal marker. The meaning of the verbal component, which can be stated 'take this as information I understand to be correct', is here contextualised by the claiming of low IS that goes with the prosodic component, and vice versa, which jointly conveys the meaning 'confirm whether you're sharing this or not'. The corresponding confirmation is accomplished by speaker B by means of another bi-modal marker, sí $\downarrow$, which combines the verbal meaning 'being in accordance with the previously expressed non-negated propositional content' with the prosodic meaning high/maximum IS.

The same bi-modal marker may convey different meanings depending on whether it appears in an initiative or in a response move. As an example, a 'no' pronounced with a risefall $(n o \uparrow \downarrow)$, when produced in an response move, will convey the maximum degree of negative IS (low mutual understanding, plus claiming the inversion of the propositional content previously uttered by the other speaker as shared knowledge); in an initiative move, however, the same marker will convey some degree of positive IS (low mutual understanding, plus claiming a high degree of shared knowledge for the propositional content previously expressed by the speaker him-/herself). In sum, the kind and degree of IS conveyed depend on (1) whether the signalling occurs in an initiative or a response move, (2) the semantic meaning of each separate component, and (3) ways in which the different components contextualise each other. 
Analysis of ISM in empirical data. In order to study how ISM is implemented in spontaneous dialogue, an episode will be examined, taken from an event in which a workgroup of Chilean higher education students are engaged in the task of preparing a didactic unit for Chilean history and society in primary education. This episode, named Ya, bacán ('Okay, brilliant!'), constitutes a side-sequence in the topic development. It is 66 seconds long, consist of 25 turns split into 35 dialogue units and has a clear beginning and end (for a full transcription of the episode, see Appendix, I). The participants are four female students of Education during their first year at university: Celia, Olaya, Paula and Tania (pseudonyms). Celia has assumed the role of secretary who writes on the computer what the group agrees on, whereas Tania consistently takes the role of chairperson.

The discussion has hitherto circled around details of the contents meant to be included in the didactic unit, when, at the start of the episode, Tania unexpectedly comes up with a problem regarding the dimension of the task:

Tania (2-3) ${ }^{\text {iii. }}$ : tengo una duda $\downarrow /$ tengo una duda como al respecto muy general $\downarrow / /$ por ejemplo si este es un contenido mínimo $\downarrow / / /$ esto de acá $\downarrow / /$ cómo nosotras vamos a hacer una unidad entera $\uparrow /$ en base a un solo contenido $\downarrow$ I have a problem, I have a sort of very general problem with this, for instance, if this is a minimal topic, this here, how are we going to make a whole unit based on one topic only?

Tania here repeatedly resorts to falling end-tones in order to claim IS for her opening point (duda $\downarrow$,general $\downarrow$ ) as well as for presupposed elements (mínimo $\downarrow$, acá $\downarrow$, contenido $\downarrow$ ), whereas the question itself - as could be expected - is pronounced with a rising tone (entera $\uparrow$ ) claiming low IS. In the turns that follow, however, more marked patterns appear:

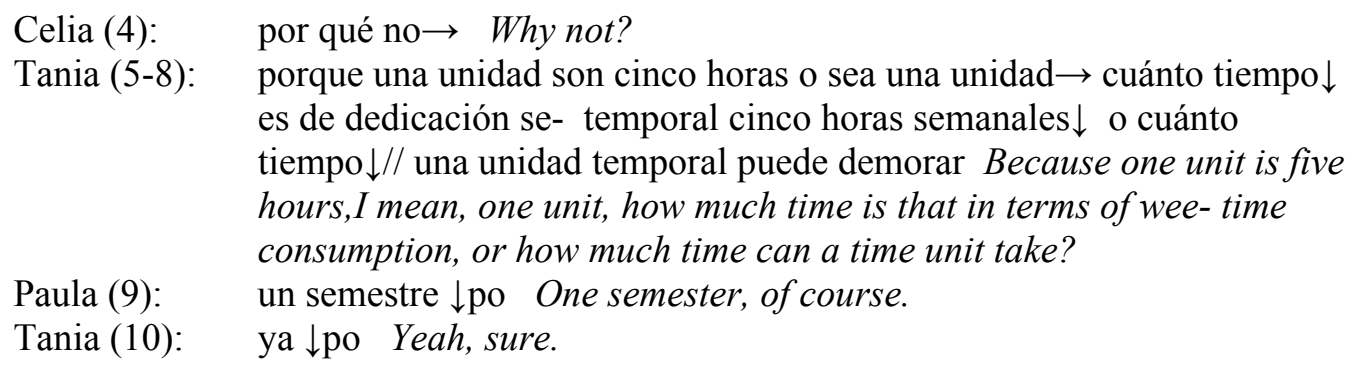

Celia (4), by means of a level end-tone, cautiously avoids making any IS claims, which compensates for her rather strong verbal questioning of the relevance of Tania's point. Tania's reaction is first to repeat the level tone (unidad $\rightarrow$ ) and then return to her affirmative style by resorting to falling end-tones, not only for expressing presupposed content (cuánto tiempo $\downarrow$ ) but also when presenting a true doubt where she actually needs to be confirmed (cinco horas semanales $\downarrow$ ). Paula (8) gives the answer, 'one whole semester', ending with a bi-modal marker, $\downarrow$ po , which gives strong emphasis to the confirmatory act performed. Tania (10) accepts this by recycling Paula's $\downarrow p o$.

In the following turns, it becomes obvious that Tania has not fully realised the difference between 'unit' and 'topic'. Paula reminds her that in this task, one unit consists of four minimal topics, an input which Tania reluctantly seems to accept. Celia and Paula jointly continue their persuasion effort:
Celia (18): es que las unidades de acá no son las mismas unidades que hacís tú $\uparrow \quad Y^{\prime}$ know, these units here are not the same units as you are doing.

Paula (19): $\quad$ en cuatro clases ya pasaste ese tema $\downarrow$ In four lessons you're already 


\section{done with that topic. \\ Tania (20): $\quad$ por eso $\downarrow$ po What I'm telling you!}

While Celia (18) by means of a rising tone claiming low IS attenuates the force of what she obviously intends to be an affirmation, Paula (19) in a more direct fashion, by means of a falling end-tone, claims high IS for the clarification she adds. Tania's (20) response is a strong confirmatory response move, por eso (literally: 'because of this'), meaning that the information referred to is precisely what she has been claiming herself. Once more she resorts to the strongly confirmatory bi-modal marker $\downarrow p o$.

After this passage, two more issues are successively resolved: the number of lessons foreseen for each minimal topic and the number of minutes foreseen for each lesson. These clarifications being made, a conclusion can be drawn regarding the dimension of a 'minimal topic':

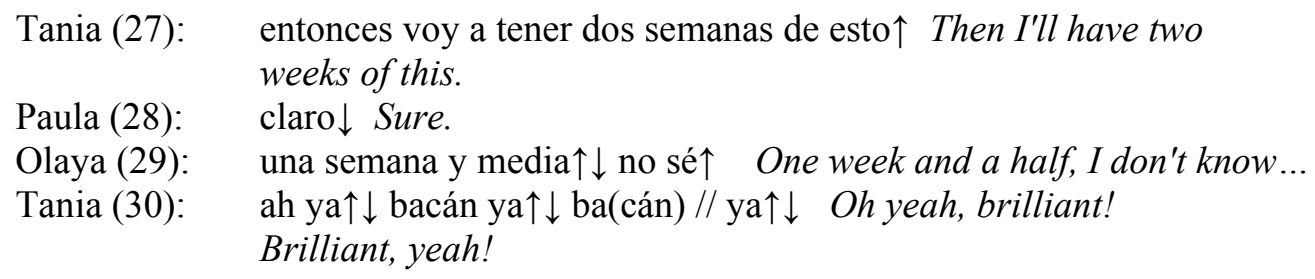

Tania (27), in spite of expressing a rather obvious conclusion, chooses to claim low IS (esto $\uparrow$ ) as a request for confirmation. Confirmation is fully granted by Paula (claro $\downarrow$, value +3 ). Olaya's (29) objection is expressed by means of a rise-fall claiming 'some degree of IS' (y media $\uparrow \downarrow,+1)$ followed by an expression of insecurity whereby low IS is being claimed (no sé $\uparrow$, value -2). This rather weak objection, however, goes unnoticed, whereas Tania (30) enthusiastically confirms her acceptance of her own conclusion. Interestingly but not surprisingly, she twice combines the minimal response marker $y a$ with a composite risingfalling end-tone. By using this bi-modal device, two meanings are simultaneously conveyed: acknowledging previous lack of mutual understanding and confirming the shared knowledge just accomplished.

In the turns that follow, Tania formulates conclusions regarding the task's dimension, and consensus is rapidly attained:

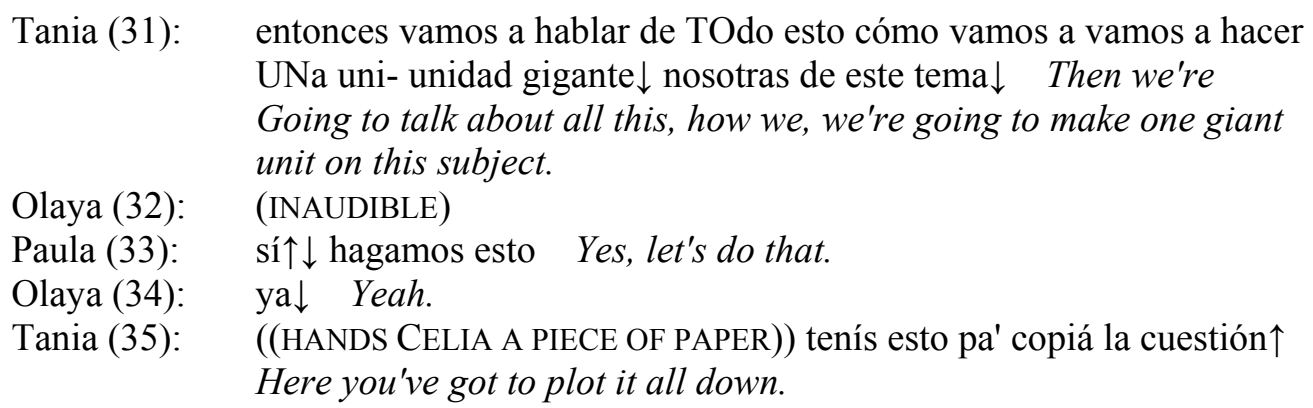

Tania (31), now more sure of herself, returns to her previous strategy of using simple falltones in order to claim high IS for, and thereby assert, her point (gigante $\downarrow$, tema $\downarrow$ ). She is confirmed both by Paula (33) and Olaya (34), the former using the bi-modal marker si $\uparrow \downarrow$, presumably conveying high IS (+2) and the latter the bi-modal marker $y a \downarrow$, conveying maximum IS $(+3)$.

The state of IS attained is indirectly confirmed by the Tania's (35) non-verbal action of handing Celia, the 'secretary', the piece of paper with the notes that she has taken. The rising 
tone with which she accompanies her request signals low IS, which is here to be understood as a non-imposing politeness strategy.

Argument management. Argumentation is a field of study situated on the borderline between social psychology and discourse linguistics. In the present context, in order to describe argument management (henceforth: AM) in dialogue, a model proposed by Gille (2001) and drawing, to a not negligible certain extent, on Jacobs and Jackson (1982), will serve as a framework.

AM moves. According to the Gille (2001) model, a series of moves are distinguished which serve argumentative purposes, and can be regarded as constituting a presumably exhaustive inventory of tools for argument management.

First, there are opening moves, of which two subcategories could be distinguished: initial opinions ( $\mathrm{IO})$ and associated opinions (AO). An 'opinion' is here understood as an explicit or partially implicit message that the speaker or speakers will orient to in the subsequent dialogue. As the term indicates, an IO is a starting point, whereas AOs are ideas connected with an IO in a metonymical relation (cause-effet, part-whole, etc.) and may emerge at any point of an episode or event. IOs can be seen as manifestations of topic introduction and AOs as manifestations of topic development.

Second, two types of simple response moves can be distinguished: acceptances (AC) and rejections (RJ). These two types are not argumentative per se, but are an essential part of AM. They can address either opinions (initial or associated) or core argumentative moves (see below).

Third, a number of argumentative core moves can be distinguished:

- supports or pro-arguments (PA) which correspond to utterances given in favour of an opinion or another core move;

- rebuttals or counter-arguments (CA) which correspond to utterances that go against an opinion or core move;

- concessions (CC), which are utterances, or parts of utterances, that lend support to an opinion, core move or general idea that goes against the speaker's main line of argumentation, often corresponding to the 'true enough' part of a 'true enough...but' sequence.

- reservations (RS) which are utterances, or parts of utterances, that qualify the strength of an $\mathrm{AC}$ or a PA.

Finally, there are two categories of moves, which without being argumentative per se constitute important links in AM: information requests (IR), and information deliveries (ID). IRs are produced in order to trigger IDs, the content of which, in turn, is typically used by the requesting part for developing his/her argumentation. On the other hand, an ID may be produced by a participant without being elicited by a preceding IR, normally with the intention of preparing the terrain for a new opening or core move.

Analysis of AM in empirical data. In a recording carried out in Madrid, two teams are opposing each other in a simulated negotiation, where the Research Department (performed by two native Spaniards, here named Jordi and Julia) and the Development Department (performed by two Swedes living in Spain, here named Arne and Lisa) try to reach an agreement about when to launch a new product developed by Research. Their interest is to have the launching done as soon as possible, while the Development representatives, disillusioned by past experience, require more tests to be done. It should be kept in mind that although the dialogue is generated from an artificial set-up, all four participants are professional negotiators and stand out as cognitively and emotionally committed to the task. 
Apart from initial instructions given to each team concerning details of the issue and goals to achieve, this role-play is entirely open-ended with a spontaneous dialogue.

In order to show the mechanisms of AM in this activity, a sequence, Las pruebas si ('The tests, right'), was chosen where the confrontation between the parties is particularly sharp. The sequence lasts for 90 seconds long and comprises 15 turns split into 33 dialogue units (for a full transcription of the sequence, see Appendix, IIa).

At the beginning of the sequence, Julia and Jordi jointly argue against Development's proposal to let the product go through a four-month testing period before launching:

Julia (1): entonces realmente esperar es- yo creo que: es es simplemente::: no sé dilatar el tema $\rightarrow$ So waiting is really, I think it simply means delaying the issue...

Jordi (2): $\quad$ sí dila- dilatar el tema y y gastar más $\downarrow$ no Yes, delaying the issue and spending more money, doesn't it?

Here, Julia (1) produces a CA ('delaying the issue'), which is recycled and further supported ('spending more money') by Jordi (2). At this point, Jordi changes his strategy and comes up with a new suggestion (AO): 'consulting the technicians'.

Jordi $(4,6)$ : $\quad$ si queréis podemos traeros a los técnicos $\uparrow$ y que tengáis una conversación con ellos $\uparrow \downarrow$ con los técnicos que han elaborado el informe $\downarrow$ no If you wish, we could bring in the technicians so you can have a talk with them, the technicians who wrote the report, right?.

Arne's direct response is to quickly accept Jordi's suggestion (Arne 7, AC) and then present an alternative topic, namely 'the costs' (Arne 8, ID):

Arne (7): $\quad$ bien $\downarrow$ Fine.

Arne (8): $\quad$ y también era el tema de de: la pasta $\downarrow$ no $\uparrow \quad$ And there was also this issue of money, wasn't there?

After an attempt to develop the topic of costs, Arne presents a revised version of his original bid, offering a three-month instead of a four-month delay (IA):

Arne (12): $\quad$ yo creo que podemos apretar un poco y hacerlo en tres meses $\downarrow$ no I believe we can squeeze it a bit and make it three months, can't we?

Julia's response is to reject Arne's offer (Julia 16; RJ) and she gives a series of arguments in support of her rejection (PO): 'insufficient time for repeating tests' (17), 'opposite party being unaware of relevant facts' $(21)$, and 'high costs' $(18,23 \mathrm{a})$ leading to 'difficulties in market introduction' $(23 \mathrm{~b}, 24)$ :

Julia (16): $\quad$ hombre en tres meses no sería posible $\rightarrow$ Oh no, in three months it wouldn't be possible,

Julia (17): porque no hay tiempo de repetir unas pruebas en tres meses-> because there's no time for repeating tests in three months.

Julia (18): por eso claro realmente: una cosa que tenemos clara que está funcioque no va a funcionar $\uparrow \downarrow /$ meternos en un proyecto de cuatro meses más/ es mucho dinero mucho:: For this reason, of course, one thing that is perfectly clear to us, that will wo-, that it won't work getting involved in a project that'll take four more months, it means a lot of money, a lot of... 
Julia (21): $\quad$ yo no sé si habéis estudiado este tema $\uparrow \downarrow I$ I don't know whether you have studied this issue.

Julia (23a): $\quad$ y esto puede cargar mucho en el precio final del del producto And this may weigh heavily on the final price of the- the product,

Julia (23b): $\quad$ y hacerlo mucho más difícil su introducción $\uparrow \downarrow$ and make it much more difficult to introduce on the market,

Julia (24): $\quad$ con lo cual e: estamos frenando $\uparrow \downarrow$ realmente el desarrollo de este: producto which means, uh, that we're putting serious obstacles to the development of this product.

At this point, Jordi opens a side-sequence asking Arne for a clarification (IR) which Arne readily provides (ID).

Jordi (26): es que yo no sé si cuando Arne comentaba esto $\uparrow$ si se refería/ a las pruebas $\uparrow$ o a lanzar el tema Actually, I don't know when Arne made his comment, whether he meant the tests or the launching.

Jordi (27): $\quad$ a qué te referías con los tres meses $\downarrow$ What did you mean by 'three months'?

Arne (28): $\quad$ a las pruebas-> a las pruebas $\downarrow$ sí The tests, right. The tests.

Jordi implicitly rejects (RJ) Arne's answer and is backed up by Julia, who formulates her rejection $(\mathrm{RJ})$ in a more explicit manner:

Jordi (30): $\quad$ tú insistes en las pruebas $\downarrow$ So you keep insisting on the tests!

Julia (32): $\quad$ no hay que hacer pruebas y ves $\rightarrow$ There is no need for any tests, and do you realise,....

Throughout this sequence, it is obvious that the fundamental conflict concerning the timing of the launching remains unresolved. No consensus is reached, except on one point (Jordi 6, Arne 7), namely that the technicians responsible for the original report should be consulted. This point, however, is not developed and the parties return to their original positions, discussing for and against the longer and the shorter delay.

Conjoining both parameters. ISM and AM belong to different planes of linguistic expression: while AM is a process characteristic of global discourse organisation, ISM is an on-line process locally implemented on the micro-level of interaction. However, in the process of co-constitutive meaning-creation, these two processes not only run parallel to, but are also dependent on, each other. In two samples of dialogue, one from each set of data, the ways in which the interlock between these processes is manifested, and to what extent it can generate consensus establishment, will be examined and discussed.

Consensus established, problem solved. Let us, to begin with, go back to the sequence $Y a$, bacán, where processes of ISM were identified and analysed. At an early stage - the exchange covering units 8,9 and10-, Tania produces an information request (IR). The answer to this request is given by Paula (ID), who confirms maximum IS. Tania's subsequent move (ya $\downarrow$ po) is an acceptance (AC) move supported by a reconfirmation of maximum IS:

Tania (8): $\quad[\ldots]$ cuánto tiempo $\downarrow / /$ una unidad temporal puede demorar For how long can a time unit last?

Paula (9): $\quad$ un semestre $\downarrow$ po One semester, of course.

Tania (10): $\quad$ ya $\downarrow$ po $\quad$ Yeah, sure. 
This exchange results in a partial consensus as regards the sub-topic 'duration of the didactic unit'. However, this consensus brings no final solution to the whole issue of the task's dimension, which means the sequence will have to continue before the preceding topic (= the content matter of the didactic unit) can be resumed. A further step forward in this endeavour can be seen in the following exchanges:

\begin{tabular}{|c|c|}
\hline lia (18): & es que las unidades de acá no son las mismas unidades que hacís tú $\uparrow$ \\
\hline aul & $\begin{array}{l}\text { en cuatro clases ya pasaste ese tema } \downarrow \text { In four lessons you're already } \\
\text { done with that topic. }\end{array}$ \\
\hline & or eso $\downarrow$ po $\quad$ What I'm telling you! \\
\hline
\end{tabular}

Here, both Celia and Paula present counter-arguments (CA) against what they perceive to be Tania's view. Celia's move is combined with a claiming of low IS (rise-tone, -2), which rather weakens her point, whereas Paula's move is connected with a claiming of high IS (fall-tone, +2 ). Tania gives her acceptance (AC) to Celia's and Paula's points in a response move that confirms maximum IS ${ }^{\mathrm{v}}$.

Since Tania has now adopted her interlocutors' views on essential points, the ground is prepared for a more comprehensive consensus to arise. A few more details need to be made clear, however, such as the number of weeks and lessons to be dedicated to each minimal topic, and the length of each lesson. After these details have been made explicit (units 21-25), the following exchange takes place between Tania and Paula:

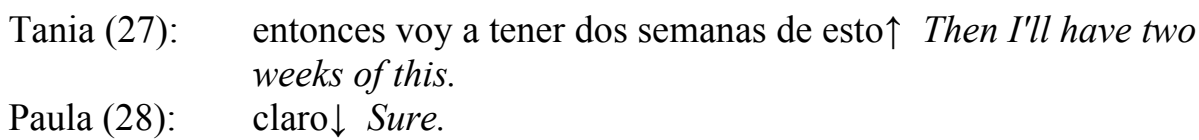

In this exchange, Tania produces an information request (IR) claiming low IS (-2). Paula responds by delivering an answer (ID) which implies the acceptance (AC) of the propositional content conveyed by Tania's utterance. Paula's choice of marker (claro $\downarrow$ ) signals the confirmation of maximum IS, which means consensus is now attained as regards the last details to be clarified. What remains to be done is to acknowledge consensus on the encompassing topic - the dimension of the task -, which is accomplished through the following exchanges:

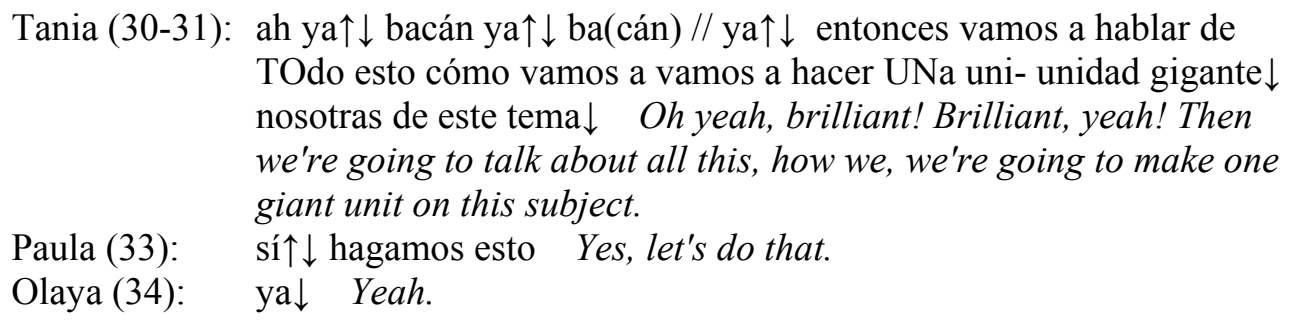

Tania, after producing a move of general acceptance (AC) and confirming high IS (ya $\downarrow$ bacán, +2), she proceeds to reformulating what she takes to be the objective of the workgroup's task. This move, from the perspective of AM, is an associated opinion (AI). From the perspective of ISM, it is a response move where the falling end-tone signals a claim for high IS (+2). Paula's and Olaya's response is to produce simultaneous acceptance moves (AC), which, in turn, are response moves confirming high IS ( +2 , Paula), and maximum IS $(+3$, Olaya), respectively. 
The result can be readily identified in the dialogue: Tania hands her hand-written piece of paper to Celia so that she can write the notes down on the computer. This action seals the consensus, marks the closing of the side-sequence, and allows the participants to return to the former topic.

In all four passages analysed, it could be observed that each accomplished step of consensus-building is based on a combination of an AM with the confirmation of high or maximum IS. Furthermore, in order for the current problem to be perceived as solved, consensus needs to be attained about all sub-topics considered relevant by the participants. Thus, AMs that can be interpreted as addressing the problematic topic as a whole are to be expected for the topic to be perceived as concluded.

Consensus established, conflict only partially solved. Conflict- and problem-solving is not always as (relatively) unproblematic as we have seen in the Ya, bacán episode. In the negotiation sequence between non-native and native participants where AM was analysed above (Las pruebas, si), the parties did not seem to get any closer to each other. In order to assess the level of consensus attained in this event, we need to look at what happens towards the end of the negotiation. In a sequence named Lo que dijimos antes ('What we said before'), AM moves will now be examined in combination with the co-occurring initiatives and responses by means of which levels of IS are claimed or confirmed. The duration of this sequence is 27 seconds and it comprises 10 turns split into 13 dialogue units (for a full transcription, see Appendix II, b).

Before the sequence starts, the Research representatives Jordi and Julia have repeated their proposal to consult the technicianswho wrote the original report. Development representative Arne accepts this proposal in a turn consisting of units 1-3 and 5:

Arne (1-2): $\quad$ bueno $\uparrow \downarrow$ podemos verlos $\rightarrow$ Okay. We can see them.

Arne (3): $\quad$ estamos a lunes hoy $\downarrow$ no $\uparrow \quad$ Today is Monday, isn't it?

Julia (4): $\quad$ ahá $\uparrow$ Aha.

Arne (5): $\quad$ e:: vernos con esta gente el el miércoles y sin falta llegar a una: a una cosa u otra $\downarrow$ no $\uparrow \quad$ Uh, see these people on Wednesday and obligatorily come to one conclusion or the other.

In this passage, Arne starts by giving his approval (AC), although with an ambiguous IS signalling: he produces a bi-modal marker (bueno $\downarrow$ ) confirming high IS $(+2)$, followed by a level end-tone signalling abstention. After this, he initiates a side-sequence by means of IR concerning which weekday it is. His request is responded to by Julia by means of an ID (aha $\uparrow$ ) where she signals a reduced degree of IS (-1), the most likely interpretation of which, however, is 'go on speaking'. Arne then continues his turn by developing the issue of when and under which conditions the meeting with the technicians is to take place. This is an associated opinion (AO) combined with a claim for low IS $(n o \uparrow,-2)$ which to be interpreted as the speaker's expectation for the opposite party to give their confirmation.

A somewhat reluctant response is provided by Jordi and Julia simultaneously:

Jordi (6): $\quad$ me parece bien $\rightarrow$ I think that's fine.

Julia (7): $\quad \operatorname{mhm} \downarrow$ Mhm.

Although both are AC moves, the ISM signal produced by Jordi (level tone) is an abstention to confirm IS, and Julia's choice of marker, albeit a signal of maximum IS, hardly reveals any enthusiasm. Accordingly, some doubts subsist whether the responses could be interpreted as establishing true consensus. Arne (8) proceeds, however, as if this was the case. He continues talking about the time of the meeting, and gets a new response from the opposite party: 
Arne (8): $\quad$ hacemos eso $\uparrow \downarrow$ lo que dijimos antes o sea por la mañana $\uparrow \downarrow$ We'll do that. What we said earlier, in the morning, that is.

Jordi (10): miércoles por la mañana $\downarrow$

Julia (11): miércoles por la mañana $\downarrow$

Arne is here simply restating his earlier AO, but now in combination with a signal of lower IS (the rise-fall twice repeated in his initiative move indicates simultaneously a low degree of mutual understanding and a high degree of shared knowledge, which sums up as signalling 'some IS', +1). His hesitation is understandable, considering the opposite party's uncommitted earlier responses. This time, however, Jordi's and Julia's acceptance moves are more unequivocally formulated and combined with signals confirming maximum IS.

At this point the parties have come to an agreement and an apparent consensus has been established - but only regarding a minor aspect: the upcoming meeting with the technicians. The basic conflict, concerning the timing of the launching and the need for more tests, has not been solved. Accordingly, it comes as no surprise when Julia continues her turn by addressing the conflictive issue once more:

Julia (12-13): lo que pasa es que sería bueno que realmente quedara claro cuál es la razón: real $\rightarrow$ o sea cuál es lo que os da miedo dentro de todo el informe que os hemos presentado de que no pueda funcionar $\uparrow \downarrow$ The thing is it would be good if you made clear which is the true reason, I mean, what makes you afraid in this whole report that we have submitted that this wouldn't work.

These observations allow us to conclude that, in the process of conflict- and problemsolving, sub-topics which have not been exhausted are likely to be re-addressed sooner or later, in spite of consensus being attained in other sub-topics, or an apparent consensus being confirmed as regards the problem as a whole.

Conclusions. In this study, two dynamic aspects of spoken interaction have been described and found to be intertwined, one being intersubjectivity management (ISM) and the other argument management (AM). ISM comprises a set of micro-level devices which are used for regulating interaction and are produced in practically every dialogue (turn-constructional) unit. In their capacity of basic tools in the co-constitution of dialogue, ISM markers are ubiquitous in all types of non-scripted interaction. AM, on the other hand, comprises a set of moves which belong to the global pragmatic plane of dialogue. AM is an essential component in a majority of spoken and written genres, and particularly so in institutional activity types. In specific types such as debates or business negotiations, AM is foregrounded and often becomes thematised.

The analysis of the two institutionally situated events considered in the present study has shown that confirming intersubjectivity at relevant points is a necessary, but not a sufficient, condition for consensus establishment. In fact, consensus-building and conflictsolving in dialogue depend crucially on the coupling between IS markers and AM moves, in the sense that only those AM moves that are supported by IS signalling become effectual. Only when an acceptance move (AC) is supported by a signal confirming high or maximum intersubjectivity, consensus can be established with regard to the topic of immediate concern.

Furthermore, the establishment of consensus concerning a topic, or group of topics, which was perceived as unresolved typically leads to the closing of that topic or topic group and, usually, to the opening of new one. If, on the other hand, topic change should occur 
without consensus having been unequivocally confirmed, the former topic will be perceived as suspended and liable to re-opening at a later stage.

\section{Transcription conventions}

$\begin{array}{ll}\text { Sign } & \text { Meaning } \\ \text { Tania } & \text { name of speaker } \\ 12 & \text { dialogue unit number '12' within the sequence } \\ \text { 12exp } & \text { expansion of unit '12' (added content matter) } \\ \text { 12ref } & \text { reformulation of unit '12' (no added content matter) } \\ \text { 12rep } & \text { repeat of unit '12' } \\ \text { (INAUDIBLE) } & \text { inaudible segment } \\ \text { (esto) } & \text { uncertain transcription } \\ \text { es UNa unidad } & \text { prominent syllable } \\ ((\text { LAUGHS)) } & \text { non-verbal action } \\ {[\quad]} & \text { overlapping segment } \\ / & \text { short silence } \sim 0.5 \text { seconds } \\ / / & \text { silence } 0.5-1.0 \text { seconds } \\ / / / & \text { silence 1.0-1.5 seconds } \\ (3.0) & \text { extended silence measured in seconds } \\ \S & \text { latching (neither pause nor overlap between turns) } \\ \text { para- } & \text { self-interruption } \\ \downarrow & \text { falling end-tone } \\ \uparrow & \text { rising end-tone } \\ \rightarrow & \text { level end-tone } \\ \uparrow \downarrow & \text { rising-falling end-tone }\end{array}$

\section{References}

Allwood, Jens, Joakim Nivre and Elisabeth Ahlsén, 'On the semantics and pragmatics of linguistic feedback', Journal of Semantics, 9: 1 (1992) 1-26.

Arundale, Robert, 'An alternative model and ideology of communication for an alternative to politeness theory', Pragmatics, 9: 1 (1999) 119-153.

Bakhtin, Mikhail, Speech genres and Other Late Essays, translated by V. McGee, edited by C. Emerson and M. Holquist (Austin, Texas: Univ. of Texas Press, 1986).

Brazil, David, The Communicative Value of Intonation in English (Cambridge: CUP, 1997).

Briz, Antonio, El español coloquial en la conversación. Esbozo de pragmagramática (Barcelona: Ariel, 1998).

Bubnova,Tatiana, 'Prólogo', in Bajtín, Mijail, Yo también soy (Fragmentos sobre el otro) (México DF: Taurus, 2000) 11-26.

Cicourel, Aaron, Cognitive Sociology (London: Cox and Wyman, 1973).

Clark, Herbert H., Using Language (Cambridge: CUP, 1996).

Clark, Herbert H. and Catherine Marshall, 'Definite reference and mutual knowledge', in Joshi, Aravind, Bonnie Webber and Ivan Sag (eds.), Elements of Discourse Understanding (Cambridge: CUP, 1981).

Donohue, William A., 'Analyzing negotiating tactics: development of a negotiation interact system', In Human Communication research, 10 (1981) 273-287.

Fant, Lars, 'Regulación conversacional en la negociación: una comparación entre pautas mexicanas y peninsulares.' In: Kotschi, Thomas, Wolf Oesterreicher and Klaus Zimmermann (eds.), El 
español hablado y la cultura oral en España e Hispanoamérica (Frankfurt am Main/ Madrid: Iberoamericana/ Vervuert, 1996) 147-183.

Fant, Lars, 'Discourse perspectives on modalisation: the case of accounts in semi-structured interviews', in Klinge, Alex and Henrik H. Müller (eds.), Modality: Studies in Form and Function (London: Equinox, 2005) 103-121.

Fant, Lars, 'La entonación: informatividad, emotividad, dialogicidad', in Hernández Alonso, César (ed.), Homenaje a Antonio Quilis, Anejos de la Revista de Filología (Madrid: Consejo Superior de Investigaciones Científicas, 2006) 183-210.

Fant, Lars, 'Negociación y modalización de la intersubjetividad en el diálogo espontáneo', in Patricia Bou, Emma Sopeña and Antonio Briz (eds.), Pragmática, discurso y sociedad (Quaderns de Filologia: Estudis Lingüístics XII, Universitat de València, 2007) 231-252.

Fant, Lars, 'Gestión de la intersubjetividad en una conversación chilena de carácter confrontativo', in Schrader-Kniffki, Martina and Laura Morgenthaler García (eds.), La Romania en Interacción: Entre historia, contacto y politica. Ensayos en homenaje a Klaus Zimmermann (Frankfurt am Main/ Madrid: Vervuert/ Iberoamericana 2007) 215-234.

Fant, Lars and Ana María Harvey, 'Intersubjetividad y consenso en el diálogo: análisis de un episodio de trabajo en grupo estudiantil', Oralia Análisis del discurso oral, Vol. 11 (in press) pp. tbc.

Gibbs, Raymond W. Jr., 'Mutual knowledge and the psychology of conversational inference', Journal of Pragmatics, 11(1987) 561-588.

Gille, Johan, Pautas argumentativas en el diálogo espontáneo: un estudio de conversaciones intra- e interculturales. Doctoral dissertation (Stockholm University, Dept. of Spanish, Portuguese and Latin American Studies, 2001).

Harvey, Ana María, 'Encuentros orales con fines de estudio: una aproximación al tema', in Falk, Johan, Johan Gille and Fernando Wachtmeister Bermúdez (eds.), Discurso, interacción e identidad. Homenaje a Lars Fant (Stockholm University, Dept of Spanish, Portuguese and Latin American Studies, 2006) 137-162.

Heritage, John, Garfinkel and Ethnomethodology (Cambridge/ New York: Polity Press, 1984).

Jacobs, Scott and Sally Jackson, 'Conversational argument: a discourse analytic approach', in Cox, J.R. and C.A. Willard, (eds.), Advances in Argumentation Theory and Research (Carbondale/Edwardsville, Illinois: Southern Illinois University Press, 1982) 205-237.

Jacoby, Sally and Elinor Ochs, 'Co-construction: an introduction', Research on Language and Social Interaction 28 (1995) 171-183.

Linell, Per, Approaching dialogue. Talk, interaction and contexts in dialogical perspectives (Amsterdam: John Benjamins, 1998).

Linell, Per, Lennart Gustavsson and Päivi Juvonen, 'Interactional dominance in dyadic communication: A presentation of initiative-response analysis', Linguistics 26 (1988) 415-442.

Núñez, Paulina and Marcela Oyanedel, 'La negociación temática en la co-construcción del conocimiento realizada por estudiantes universitarios', Revista Signos (in press) pp. tbc.

Navarro Tomás, Tomás, Manual de entonación española (New York: Hispanic Institute, 1944).

Ortega Olivares, Jenaro, 'Apéndices modalizadores: los comprobativos', in Montoya Martínez, J. and J. Paredes Nuñes (eds.), Estudios Rómanicos dedicados al Prof. Andrés Soria Ortega (Universidad de Granada 1985) 239-255.

Rommetveit, Ragnar, 'On the architecture of intersubjectivity', in Rommetveit, R. and R.M. Blakar (eds.), Studies in language, thought and verbal communication (London: Academic Press, 1979) 93-108.

Rommetveit, Ragnar, 'Language Acquisition as Increasing Linguistic Structuring of Experience and Symbolic Behaviour Control', in Wertsch, James V. (ed.), Culture, Communication and Cognition. (Cambridge: Cambridge University Press, 1985) 183-204.

Sacks, Harvey, Emmanuel Schegloff, Emmanuel and Gail Jefferson, 'A simplest systematics for the organization of turn-taking in conversation', Language 50 (1974) 696-735.

Schegloff, Emmanuel, 'Discourse as an Interactional Achievement', in Tannen, Deborah (ed.), Analyzing Discourse: Text and Talk (Washington, DC: Georgetown University Press, 1982) 7393.

Selting, Margret, 'On the interplay of syntax and prosody in the constitution of turn-constructional units and turns in conversation', Pragmatics, 6: 3 (1996) 371-388. 
Taylor, Martin M., Françoise Neel and Don G. Bouwhuis (eds.), Structure of Multi-Modal Dialog

(New York: Elsevier Science, 1989).

Wertsch, James V., Voices of the Mind (New York: Harvester Wheatsheaf, 1991).

Wertsch, James V., Mind as Action (New York/Oxford: OUP, 1998).

Vázquez Veiga, Nancy, 'Respuestas mínimas reguladoras: los límites de la marginalidad', Oralia Análisis del discurso oral, Vol. 3 (2000) 221-242.

Yngve, Victor, 'On getting a word in edgewise', in Chicago Linguistic Society, Papers from the Sixth Regional Meeting. (University of Chicago, 1970) 567-577.

\section{Appendix: samples for analysis.}

I. Problem-solving in a student workgroup. Episode 'Ya, bacán'. Source: Corpus 'GRUPES', event VI, 2:33:32 - 2:34:38 (= 66 secs).

\begin{tabular}{|c|c|c|}
\hline 1 & Paula & del:: la bandera $\uparrow /$ \\
\hline 1ref & & del: blablablá $\uparrow \S$ \\
\hline 2 & Tania & §tengo una duda $\downarrow /$ \\
\hline $2 \exp$ & & tengo una duda como al respecto muy general $\downarrow / /$ \\
\hline 3 & & por ejemplo si este es un contenido mínimo $\downarrow / / /$ \\
\hline $3 \exp$ & & esto de acá $\downarrow / /$ \\
\hline $3 \exp$ & & cómo nosotras vamos a hacer una unidad entera $\uparrow /$ \\
\hline $3 \exp$ & & en base a un solo contenido $\downarrow$ \\
\hline 4 & Celia & $(2.0)$ por qué no $\rightarrow$ \\
\hline 5 & Tania & (2.0) porque una unidad son cinco horas \\
\hline 6 & & o sea una unidad cuánto tiempo $\downarrow$ es de dedicación se- temporal \\
\hline 7 & & cinco horas semanales $\downarrow$ \\
\hline 8 & & o cuánto tiempo $\downarrow / /$ \\
\hline $8 \mathrm{exp}$ & & una unidad temporal (puede demorar) $\S$ \\
\hline 9 & Paula & §un semestre $\downarrow$ po \\
\hline $9 \exp$ & & (INAUDIBLE) $\S$ \\
\hline 10 & Tania & $\S \mathrm{ya} \downarrow$ po \\
\hline 11 & & no vai a hacer un semestre entero en un solo tema $\downarrow \downarrow p o \S$ \\
\hline 12 & Paula & $\S$ no $\downarrow$ po \\
\hline 13 & & de estos cuatro $\uparrow \downarrow$ po \\
\hline 14 & Tania & ya $\downarrow$ po \\
\hline 15 & & es que lo que nosotros vamos a hacer es UNa unidad $\downarrow$ \\
\hline 15ref & & no más§ \\
\hline 16 & Paula & $\S \mathrm{mm}: \rightarrow \S$ \\
\hline 17 & Tania & §aah entonces [(INAUDIBLE)] \\
\hline 18 & Celia & $\begin{array}{l}\text { [es que las unidades de acá no son las mismas unidades] que } \\
\text { [hacís tú } \uparrow]\end{array}$ \\
\hline 19 & Paula & [en] cuatro clases ya pasaste ese tema $\downarrow /$ \\
\hline 20 & Tania & por eso $\downarrow$ po \\
\hline 21 & & $\begin{array}{l}\text { entonces nosotras vamos a hacer diez } \uparrow \downarrow \text { ((SOMEONE KNOCKS AT } \\
\text { THE DOOR)) }\end{array}$ \\
\hline $21 \exp$ & & clases $\S$ \\
\hline 22 & Paula & $\S$ no: $\uparrow \downarrow$ \\
\hline 23 & & vai a hacer cinco clases $\downarrow \S$ \\
\hline 24 & Celia & $\S$ no \\
\hline 25 & & porque piensa que los niños tienen $\uparrow$ ya $\uparrow \downarrow$ noventa minutos $\S$ \\
\hline 26 & Olaya & $\S$ cuántos son $\uparrow$ \\
\hline 26ref & & cuántas semanas [cuánt-] \\
\hline
\end{tabular}




\begin{tabular}{|c|c|c|}
\hline 27 & Tania & [entonces voy a] tener dos semanas [de esto $\uparrow]$ \\
\hline 28 & Paula & {$[$ claro $\downarrow]$} \\
\hline 29 & Olaya & una semana y media $\uparrow \downarrow$ \\
\hline $29 \exp$ & & no sé $\uparrow$ \\
\hline 30 & Tania & ah ya $\uparrow \downarrow$ bacán \\
\hline 30rep & & ya $\uparrow \downarrow$ ba(cán) // \\
\hline 30rep & & $\mathrm{ya} \uparrow \downarrow$ \\
\hline 31 & & entonces vamos a hablar de TOdo esto \\
\hline $31 \exp$ & & $\begin{array}{l}\text { cómo vamos a [vamos a hacer] UNa uni- unidad gigante } \downarrow \\
\text { nosotras }\end{array}$ \\
\hline 32 & Olaya & [(INAUDIBLE)] \\
\hline $31 \exp$ & Tania & [de este te]ma $\downarrow$ \\
\hline 33 & Paula & 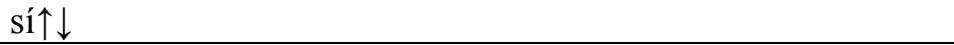 \\
\hline $33 \exp$ & & [haga]mos (esto) $\S$ \\
\hline 34 & Olaya & {$[\mathrm{ya} \downarrow]$} \\
\hline 35 & Tania & $\begin{array}{l}((\text { HANDS WRITTEN NOTES TO CELIA)) §tenís (esto) pa copiá la } \\
\text { cuestión } \uparrow\end{array}$ \\
\hline
\end{tabular}

IIa. Business negotiation, sequence 'Las pruebas, si'. Source: Corpus 'AKSAM', recording 39, 0:11:28-0:12:58 (=90 secs).

\begin{tabular}{|c|c|c|}
\hline 1 & Julia & entonces realmente esperar es- \\
\hline $1 \mathrm{exp}$ & & yo creo que: es es simplemente::: no sé dilatar [el tema $\rightarrow$ ] \\
\hline 2 & Jordi: & [sí dila-]dilatar el tema [y y gas]tar más $\downarrow$ no \\
\hline 3 & Julia: & {$[\mathrm{mhm} \rightarrow]$} \\
\hline 4 & Jordi: & si queréis podemos traeros a los [técnicos $\uparrow]$ \\
\hline 5 & Julia: & {$[\mathrm{mhm} \uparrow]$} \\
\hline 6 & Jordi: & y que tengáis una conversación con ellos $\uparrow \downarrow$ \\
\hline $6 \exp$ & & con los técnicos que han elaborado el informe $\downarrow$ [no] \\
\hline 7 & Arne: & {$[$ bien $\downarrow]$} \\
\hline 8 & & y también era el tema de de: la pasta $\downarrow$ no $\uparrow$ \\
\hline 9 & & si tenemos presupuesto para para- \\
\hline 10 & & si el tiempo $\uparrow /$ \\
\hline 11 & & bueno/ en cuatro:: \\
\hline 12 & & yo creo que podemos apretar un poco y hacerlo en tres meses $\downarrow$ no $\S$ \\
\hline 13 & Julia: & $\S \mathrm{mhm} \rightarrow \S$ \\
\hline $12 \exp$ & Arne: & §para ver cómo estamos \\
\hline 14 & & $\begin{array}{l}\text { y bueno } \downarrow \text { hablaremos con: con los financieros y veremos si:: es } \\
\text { factible } \downarrow \text { no }\end{array}$ \\
\hline $14 \mathrm{exp}$ & & desde el punto de vista/ presupuesto $\uparrow /$ [y y] liquidez $\uparrow \downarrow$ \\
\hline 15 & Jordi: & {$[$ claro $\downarrow]$} \\
\hline 16 & Julia: & hombre en tres meses no sería posible $\rightarrow$ \\
\hline 17 & & porque no hay tiempo de repetir unas pruebas en tres meses $\rightarrow$ \\
\hline 18 & & $\begin{array}{l}\text { por eso claro realmente: una cosa que tenemos clara que está } \\
\text { funcio- que no va a funcionar } \uparrow \downarrow /\end{array}$ \\
\hline $18 \exp$ & & meternos en un proyecto de cuatro meses más \\
\hline 19 & & que es lo que podría lleva:r esto con el consiguiente personal $\uparrow$ \\
\hline $18 \exp$ & & es mucho dinero mucho: $\rightarrow$ \\
\hline 20 & & $\begin{array}{l}\text { realmente es mucho dinero para la compañía para algo que no/ } \\
\text { creemos que pueda cambiar absolutamente nada } \uparrow \downarrow\end{array}$ \\
\hline
\end{tabular}




\begin{tabular}{|l|l|l|}
\hline 21 & & yo no sé si habéis estudiado este tema $\uparrow \downarrow$ \\
\hline 22 & & pero es importante $\uparrow \downarrow$ hablando: de dine:ro \\
\hline 23 & & y esto puede cargar mucho en el precio final del del producto $\uparrow$ \\
\hline $23 \exp$ & & y hacerlo mucho más difícil su introducción $\uparrow \downarrow$ \\
\hline 24 & & $\begin{array}{l}\text { con lo cual } \uparrow \text { e: estamos frenando } \uparrow \downarrow \text { realmente el desarrollo de es[te: } \\
\text { producto] }\end{array}$ \\
\hline 25 & Jordi: & {$[$ oye perdona] Julia $\uparrow \downarrow$} \\
\hline 26 & & es que yo no sé si cuando Andrés comentaba esto $\uparrow$ \\
\hline 26 exp & & si se refería/ a las pruebas $\uparrow$ o a lanzar ya el tema $\downarrow$ \\
\hline 27 & & a qué te referías con los tres meses $\downarrow \S$ \\
\hline 28 & Arne: & §a las pruebas $\rightarrow$ \\
\hline 28 rep & & a [las pruebas $\downarrow$ sí] \\
\hline 29 & Jordi: & a las pruebas $\downarrow$ \\
\hline 30 & & tú insistes en las pruebas $\downarrow$ \\
\hline 31 & & no quieres- $\S$ \\
\hline 32 & Julia: & §no hay que hacer pruebas \\
\hline 33 & & y ves $\rightarrow[\ldots]$ \\
\hline
\end{tabular}

IIb. Business negotiation, sequence 'Lo que dijimos antes'. Source: Corpus 'AKSAM', recording $39,0: 31: 17-0: 31: 44$ (= 27 secs).

\begin{tabular}{|c|c|c|}
\hline 1 & Arne: & bueno $\uparrow \downarrow$ \\
\hline 2 & & podemos verlos- $>$ \\
\hline 3 & & estamos a lunes hoy $\downarrow$ no $\uparrow \S$ \\
\hline 4 & Julia: & §ajá $\uparrow \S$ \\
\hline 5 & Arne: & $\begin{array}{l}\S \mathrm{e}:: \text { vernos con esta gente el el miércoles y sin falta llegar a una: a } \\
\text { una cosa u otra } \downarrow \text { no } \S\end{array}$ \\
\hline 6 & Jordi: & $\S$ me parece [bien->] \\
\hline 7 & Julia: & {$[\mathrm{mhm} \downarrow]$} \\
\hline 8 & Arne: & hacemos eso $\uparrow \downarrow$ \\
\hline 9 & Jordi & sí yo creo que- $\S$ \\
\hline $8 \exp$ & Arne & §lo que dijimos antes \\
\hline $8 \exp$ & & o sea por la [mañana $\uparrow \downarrow]$ \\
\hline 10 & Jordi & [miércoles] por la [mañana $\downarrow]$ \\
\hline 11 & Julia & [miércoles por la] mañana $\downarrow$ \\
\hline 12 & & $\begin{array}{l}\text { lo que pasa es que sería bueno que realmente quedara claro cuál es la } \\
\text { razón: real } \rightarrow\end{array}$ \\
\hline 13 & & $\begin{array}{l}\text { o sea cuál es lo que a vosotros os da miedo dentro de todo el informe } \\
\text { que os hemos presentado de que no pueda funcionar } \uparrow \downarrow / /\end{array}$ \\
\hline
\end{tabular}

\footnotetext{
${ }^{\mathrm{i}}$ The present study draws largely on, and parts of the analysis roughly coincide with, Fant and Harvey (in press).

ii An important contribution to the description of these markers, however, is Ortega Olivares (1985), who terms them comprobativos ('checkers' or 'uptakers').

${ }^{\text {iii }}$ The numbers within parentheses refer to the order of dialogue (turn constructional) units within the episode.

${ }^{\text {iv }}$ Falling end-tones are characteristic of WH-questions and either occur at the question word itself or at the end of the unit. Their meaning is to claim IS for the presupposed part of the questions.

${ }^{v}$ At the same time, Tania (20) includes an initiative conveying the meaning 'this is what I already meant to say", which is obviously untrue.
} 